\title{
GESTÃO DE MARCAS
}

A preocupação com a marca é histórica. No antigo Egito, por exemplo, os fabricantes de tijolos já imprimiam símbolos em seus produtos para identificá-los. A marca é a característica mais poderosa para a formação da imagem de um produto, pois, na ausência de qualquer outro referencial, será o mais importante sinal a partir do qual o consumidor avaliará um produto. Consumidores mais exigentes e a demanda por qualidade e opções de escolha fazem da construção de novas marcas, sem dúvida, um desafio. Seguem indicações bibliográficas do professor Rubens da Costa Santos, do Departamento de Mercadologia da FGV-EAESP, compiladas por Deise Spada.

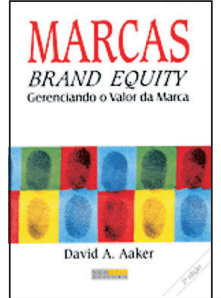

BRAND EQUITY: gerenciando o valor da marca

David A. Aaker. São Paulo : Negócio, 1998. 310 p.

É um clássico sobre o assunto que expõe, de maneira integrada, como fazer gerenciamento de marca. O autor apresenta a estrutura da relação entre a marca e seu símbolo ou slogan, abrindo cada capítulo com uma análise histórica do sucesso ou fracasso de alguma empresa na construção de sua marca - o que propicia aos gerentes uma visão mais clara de como o brand equity efetivamente proporciona valor.

\section{STRATEGIC BRAND MANAGEMENT:}

new approaches to creating and evaluating brand equity Jean-Noël Kapferer. New York : Free Press, 1992. 341 p.

Kapferer é uma autoridade internacional em gestão de marcas e marketing. Por meio de vários exemplos e estudos de casos do mundo todo, o autor retrata uma visão geral de cada aspecto da gestão de marcas, além de destacar seus perigos e armadilhas.

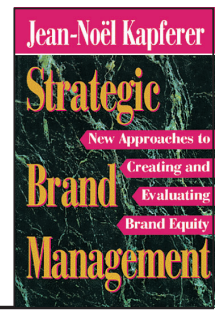

\section{Building Brands Directly}

\section{BUILDING BRANDS DIRECTLY:}

creating business value from customer relationship Stewart Pearson. Basingstoke : MacMillan Business, 1996. 432 p.

Esse livro aborda, sob a ótica do consumidor, todos os aspectos da gestão de marcas. Pearson discute como construir e garantir a sobrevivência de sua marca mediante investimentos na lealdade de seus consumidores, em um ambiente de intensa competição e mercados fragmentados.

\section{A FORÇA DA MARCA: como construir e manter marcas fortes} Mauro Calixta Tavares. São Paulo : Harbra, 1998. 220 p. Livro elaborado a partir da tese de doutoramento do autor, cujo objetivo é, passo a passo, identificar os elementos responsáveis pela construção do valor de marca e sua interação com os fatores mais importantes para o consumidor. A característica marcante da abordagem dessa obra é a operacionalização dos conceitos associados à gestão da marca.

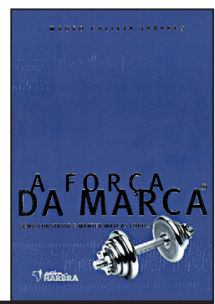

